\title{
Spectral analysis of atmospheric composition: application to surface ozone model-measurement comparisons
}

\author{
Dene R. Bowdalo, Mathew J. Evans, and Eric D. Sofen \\ Wolfson Atmospheric Chemistry Laboratories, Department of Chemistry, University of York, Heslington, York, \\ YO10 5DD, UK \\ Correspondence to: Dene R. Bowdalo (denebowdalo@googlemail.com)
}

Received: 26 February 2016 - Published in Atmos. Chem. Phys. Discuss.: 14 March 2016

Revised: 7 June 2016 - Accepted: 15 June 2016 - Published: 11 July 2016

\begin{abstract}
Models of atmospheric composition play an essential role in our scientific understanding of atmospheric processes and in providing policy strategies to deal with societally relevant problems such as climate change, air quality, and ecosystem degradation. The fidelity of these models needs to be assessed against observations to ensure that errors in model formulations are found and that model limitations are understood. A range of approaches are necessary for these comparisons. Here, we apply a spectral analysis methodology for this comparison. We use the LombScargle periodogram, a method similar to a Fourier transform, but better suited to deal with the gapped data sets typical of observational data. We apply this methodology to long-term hourly ozone observations and the equivalent model (GEOS-Chem) output. We show that the spectrally transformed observational data show a distinct power spectrum with regimes indicative of meteorological processes (weather, macroweather) and specific peaks observed at the daily and annual timescales together with corresponding harmonic peaks at one-half, one-third, etc., of these frequencies. Model output shows corresponding features. A comparison between the amplitude and phase of these peaks introduces a new comparison methodology between model and measurements. We focus on the amplitude and phase of diurnal and seasonal cycles and present observational/model comparisons and discuss model performance. We find large biases notably for the seasonal cycle in the mid-latitude Northern Hemisphere where the amplitudes are generally overestimated by up to $16 \mathrm{ppbv}$, and phases are too late on the order of 1-5 months. This spectral methodology can be applied to a range of model-measurement applications and is highly suitable for Multimodel Intercomparison Projects (MIPs).
\end{abstract}

\section{Introduction}

Ozone $\left(\mathrm{O}_{3}\right)$ at the surface is a pollutant, harmful to both human and plant health (WHO, 2005; Fowler et al., 2009). It is the dominant source of the hydroxyl radical $(\mathrm{OH})$ (Levy, 1972), which controls the concentration of key climate gases $\left(\mathrm{CH}_{4}, \mathrm{HCFCs}\right.$, etc. $)$ and is an important climate gas in its own right (Forster et al., 2007).

The main sources of $\mathrm{O}_{3}$ in the troposphere are from photochemical production and transport from the stratosphere. It is lost through dry deposition and photochemical loss (Monks et al., 2000; Stevenson et al., 2006; Monks et al., 2015). In the troposphere $\mathrm{O}_{3}$ photochemical production is driven by the emission of precursors: nitrogen oxides $\left(\mathrm{NO}_{x}\right)$, carbon monoxide $(\mathrm{CO})$, methane $\left(\mathrm{CH}_{4}\right)$, and volatile organic compounds (VOCs), which in the presence of appropriately energetic photons can lead to a complex set of reactions, which ultimately produce $\mathrm{O}_{3}$ in a non-linear fashion (Ehhalt, 1999; Jenkin and Clemitshaw, 2000; Monks, 2005).

Our understanding of tropospheric ozone comes from observations of the spatial and temporal distribution of ozone and its precursors together with numerical simulations. Given the lifetime of tropospheric ozone ( $\sim 22$ days) (Stevenson et al., 2006), global models either online (chemistry transport models - CTMs) or offline (Earth system models - ESMs) are particularly useful and are used extensively. An assessment of model fidelity is essential to find errors in processes, to evaluate where model processes are inadequate, and to understand when models provide useful predictive capabilities.

Depending on the emphasis of the study, a range of methodologies have been applied to model-measurement comparisons for ozone. Many have used comparisons to 
"long-term" surface ozone observations as a basis (Tanimoto et al., 2005; Jonson et al., 2006; Oltmans et al., 2006; Derwent et al., 2008; Cooper et al., 2012; Logan et al., 2012; Hess and Zbinden, 2013; Oltmans et al., 2013; Parrish et al., 2013, 2014). Typically, these observations are averaged onto a monthly timescale and compared to a similarly averaged model output, and the two compared as a function of time. This offers some advantages. The averaged measurement and modelled data sets are small, making comparisons compact and easy to understand. It also removes the short-term variability ( $<$ monthly) that may not be of interest to the researchers.

However, this approach also suffers from a range of limitations. Processes occurring on timescales shorter than monthly include photochemistry, deposition, transport, and emission, all of which are important to the success of the model. By focusing on the monthly variability alone other timescales are ignored, which may lead to an insufficiently robust analysis of model performance. What is required is a methodology to assess model fidelity on a range of timescales simultaneously. Spectral methods offer this approach but atmospheric chemistry has only been used in a small number of studies, and specifically for ozone in a limited sense, fitting stand-alone sine waves to time series (Schnell et al., 2015) and applied to a small selection of coarse monthly average data (Parrish et al., 2016).

In this paper we introduce a methodology for the spectral analysis of observations of atmospheric composition data (Sect. 2). We describe this methodology for two contrasting sites (Sect. 3). We then show this methodology applied to a range of surface ozone observations sites (Sect. 4), and applied to a CTM (Sect. 5). We then compare these results and finally discuss potential reasons for biases (Sect. 6).

\section{Spectral methods}

The decomposition of a time series into a set of orthogonal periodic functions was first suggested by Joseph Fourier. Classically, this decomposition yields a number of sinusoidal waves each with an associated amplitude and phase. This technique is used extensively in disciplines such as engineering and geophysics. Using a computer to compute this decomposition, traditionally by correlation of basis functions with a time series, is termed the discrete Fourier transform (DFT). However, this method is computationally intense, which led to the development of the fast Fourier transform (FFT). One of the limitations of the FFT is that it cannot accurately handle data sets with irregular time intervals. Some kind of interpolation is needed to provide data on a regular time interval, which biases results (particularly at high frequencies) (Press et al., 1992; Schulz and Stattegger, 1997; Musial et al., 2011; Rehfeld et al., 2011). Atmospheric observations inherently have irregular time intervals due to instru- mental issues (power breaks, instrument failures, calibration times, etc.) so another numerical method is needed.

The Lomb-Scargle periodogram (LSP) is a spectral analysis method designed to handle gapped data sets (Lomb, 1976; Scargle, 1982; Horne and Baliunas, 1986; Press and Rybicki, 1989; Press et al., 1992), which has been applied in a small number of instances to air quality data (Dutton et al., 2010; Stefan et al., 2010). It can be formulated as a modified DFT (Scargle, 1982; Press et al., 1992), and also equivalently by the least squares of fit of sine and cosine waveforms to a time series centred around zero (Lomb, 1976). Using the modified DFT methodology, for an equally spaced time series, taking the magnitude squared of the dot products of a time series (centred around zero) with cosine and sine waveforms at set frequencies gives a spectrum that is an estimate of the power contributing to the original data. In the presence of data gaps, the sine and cosine model functions are modified to be exactly orthogonal by an additional phase parameter $\Theta$ (Scargle, 1982), making the estimation invariant to shifts in time of the input time series (i.e. data gaps). It is commonly represented in its normalised form (termed Power Spectral Density), e.g. (Press et al., 1992), as

$$
\begin{aligned}
& P(\omega)= \\
& \frac{1}{2 \sigma^{2}}\left(\frac{\left[\sum_{i=1}^{N} y\left(t_{i}\right) \cos \left(\omega t_{i}-\Theta\right)\right]^{2}}{\sum_{i=1}^{N} \cos ^{2}\left(\omega t_{i}-\Theta\right)}+\frac{\left[\sum_{i=1}^{N} y\left(t_{i}\right) \sin \left(\omega t_{i}-\Theta\right)\right]^{2}}{\sum_{i=1}^{N} \sin ^{2}\left(\omega t_{i}-\Theta\right)}\right),
\end{aligned}
$$

where $y\left(t_{i}\right)$ is the observable at time $t_{i}, \omega$ is the angular frequency, and $\sigma^{2}$ is the variance of the time series. The phase offset $\Theta$ is calculated with the four quadrant inverse tangent, shown by Eq. (2). Additionally, the DFT is modified so when data gaps exist the distribution of the normalised spectrum for pure Gaussian noise is exponential, equivalent to that of the equal spaced case.

$$
\Theta=\frac{1}{2} \arctan \left(\sum_{i=1}^{N} \sin \left(2 \omega t_{i}\right), \sum_{i=1}^{N} \cos \left(2 \omega t_{i}\right)\right)
$$

The LSP does not output any phase information natively. However, Hocke (1998) gave a method to modify the LSP algorithm to output real and imaginary components or amplitude and phase, as a result of the Fourier transform, which we apply in our work.

\section{Spectral leakage}

There are some problems in accurately identifying the amplitude and phase of periodic components. The main issue is termed "spectral leakage". Typically, Lomb-Scargle methods calculate power at integer frequencies equally spaced between one (total span of time series) and one-half of the average sampling frequency (termed "average Nyquist frequency"), reflecting the Fourier frequencies. If strong periodicity exists on a frequency, not an integer integral on the span 
of the time series, then its power would lie between two of the frequencies, resulting in leakage of that power throughout the rest of the spectrum. Atmospheric time series are not typically integer-year long. For example, if the time series was 10.5 years long the spectrum would consist of the periods: $10.5,5.25,3.5,2.1, \ldots, 1.16,1.05,0.955$ years, etc. Therefore, if large variability were contained on exactly a 1year cycle, the LSP would spread that power throughout the spectrum.

Spectral leakage results from an assumption in spectral analysis methods that the time record is infinitely long. The transform assumes that the finite data set is one period of an infinite periodic signal. Therefore, when the periodicity of interest is non-harmonic with the total span of the time record, there is a discontinuity, which results in leakage in the spectral domain (Horne and Baliunas, 1986).

To ensure the power leakage from multiple periodic components does not contaminate the entire spectrum, the input time series can be multiplied by a window function (Harris, 1978). The window is shaped so that it is zero at the beginning and end, and has some defined shape in between. The window effectively changes the shape of the leakage in the frequency domain, limiting its impact to only a few frequencies around the peak frequency, providing a trade-off between peak resolution (the width of the peak) and spectral leakage (the amplitude of the tails of the leakage), with different windows altering the peaks of the spectrum in different ways. In this study a Hanning window was chosen as it offers an acceptable trade-off between resolution and spectral leakage (Harris, 1978).

Although the shape of the leakage can be altered, the peak amplitude will still be underestimated as there are no frequencies that estimate exactly at the exact frequency of interest. However, the LSP methodology (unlike the FFT) can estimate at any frequency, allowing the exact capturing of the top of the peak. Thus, if significant cycles are known a priori (annual, daily, etc.) their sinusoids can be calculated very accurately.

\section{Lomb-Scargle periodogram of surface ozone}

Figure 1 shows the time series of hourly surface ozone mixing ratios collected at Cabo Verde (Carpenter et al., 2010) and Lompoc together with equivalent model output (see Sect. 5). Cabo Verde $\left(16.51^{\circ} \mathrm{N}, 24.52^{\circ} \mathrm{W}\right)$ is a small remote island country consisting of 10 islands situated in the tropical eastern North Atlantic Ocean, $570 \mathrm{~km}$ off the West African coast. It represents one of the only ozone measurement stations in the tropics, and is relatively undeveloped, also making it one of the small number of baseline oceanic measurement sites. It is maintained by the atmospheric chemistry group at the University of York, and thus presents a readily available data set for analysis. Lompoc $\left(34.73^{\circ} \mathrm{N}, 120.43^{\circ} \mathrm{W}\right)$, is a USA environmental protection agency air quality system

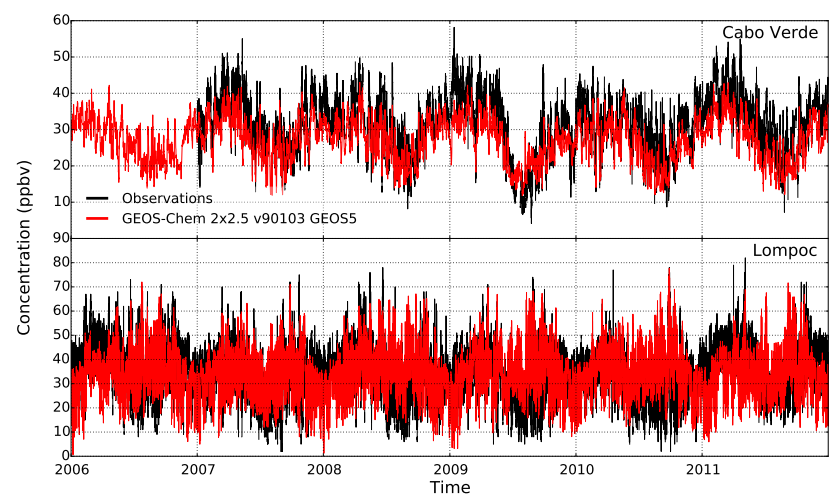

Figure 1. Time series of surface $\mathrm{O}_{3}$ at Cabo Verde $\left(16.51^{\circ} \mathrm{N}\right.$, $\left.24.52^{\circ} \mathrm{W}\right)$ and Lompoc $\left(34.73^{\circ} \mathrm{N}, 120.43^{\circ} \mathrm{W}\right)$ for the observations (black) and the GEOS-Chem model (red), between 2006 and 2012.

(EPA AQS) rural continental site located on the US Californian west coast. Using the Lomb-Scargle methodology, the time series at Cabo Verde and Lompoc can be transformed into a number of sinusoidal waves at a range of periods with differing amplitudes and phases. In Fig. 2 we show the amplitude (ppbv) of these waves as a function of their period (days).

The spectra for both sites shown in Fig. 2 have a range of characteristic features. There are broadly linear regions from $2 \mathrm{~h}$ to 10 days and from 10 days to the last period of 1826 days. There are also sets of peaks, which occur at characteristic timescales (i.e. 1 day and 1 year). We will initially discuss the identification of these linear regimes and then discuss the identification of the peaks.

\subsection{Meteorological regimes}

Figure 2 shows two distinct linear regimes for both sites' spectra in the value of the amplitude of the waves making up the LSP, which meet at around 10 days. Very similar spectra are seen in physical parameters in the atmosphere (Lovejoy and Schertzer, 2013a, b). There are three main scaling regimes of meteorological variability (Lovejoy and Schertzer, 2013a, b): "weather", "macroweather", and "climate", with each regime being the outcome of different dynamical processes.

Weather processes range from microscale local turbulence to planetary-scale weather systems, with the temporal lifetimes of these features roughly proportional to their spatial scale (Lovejoy and Schertzer, 2013b). The variability induced on $\mathrm{O}_{3}$ also scales accordingly to these; thus, the weather regime for $\mathrm{O}_{3}$ is represented by a steep spectral gradient (on the log-log spectrum - Fig. 2) from $2 \mathrm{~h}$ to $\sim 10$ days, after which there is a sharp transition to a flatter gradient. The change in the gradient at around 10 days is physically caused by the finite size of the Earth giving a limit to the lifetime of the biggest planetary-scale weather systems. After $\sim 10$ days the flat spectral gradient is a result 
of being the average of the largest planetary-scale weather systems, being no more than low-frequency weather, with no new dynamical elements or forcing mechanism, the statistics of this regime being well captured by unforced "control" runs of general circulation models (Lovejoy and Schertzer, 2013a). The regime has been shown for metrological spectra to extend out to 10-100 years, and is termed "macroweather" (Lovejoy and Schertzer, 2013b). The final regime is characterised by a steep increase from the flat macroweather gradient between 10 and 100 years caused by new (internal) low-frequency non-linear interactions or (external) solar, volcanic, or anthropogenic forcings, and represents longterm changes of the macroweather. Human induced changes would be termed "climate change". As our work only uses time series of 5 years in we do not see evidence of any climate regime for our spectra. We thus we end up with two regimes to describe the impact of meteorology on surface $\mathrm{O}_{3}$ variability: weather ( $2 \mathrm{~h}-10$ days) and macroweather ( $>10$ days).

These regimes can be described by fitting a model of two joint piecewise linear functions in $\log -\log$ space to the spectrum (minimising the residuals). We set the transition point at 10 days, as the theoretical maximum lifetime for the largest planetary-scale weather systems (Lovejoy and Schertzer, 2013b). We only use periods less than 100 days, for the few points beyond this value are noisy and can often introduce significant variability into this fitting. The upper panels of Fig. 2 show the linear fits (green line) to the observed surface $\mathrm{O}_{3}$ spectra for both Cabo Verde and Lompoc.

To find periods that deviate from these fits, we scale the fitted models by percentiles of the chi-squared probability distribution to obtain false-alarm levels (Schulz and Mudelsee, 2002). Peaks exceeding these false-alarm levels indicate nonmodel components in the time series, and should be considered significant (Schulz and Mudelsee, 2002). Here, we take frequencies that have an amplitude above the 99th percent confidence level to be significant. Our attention now focuses on these significant frequencies, namely the annual and daily peaks (and their harmonics).

\subsection{Annual and daily cycles}

From Fig. 2 it is evident that there are significant peaks on annual and daily timescales for both Cabo Verde and Lompoc. There are also additional significant harmonic peaks $\left(\frac{1}{2}\right.$ daily for Cabo Verde; $\frac{1}{2}, \frac{1}{3}, \frac{1}{4}, \frac{1}{5}, \frac{1}{6}, \frac{1}{7}, \frac{1}{8}, \frac{1}{9}, \frac{1}{10}, \frac{1}{11}, \frac{1}{12}$ daily and $\frac{1}{2}$ annual for Lompoc). These periodic cycles are driven by the planetary processes of the Earth's rotation around its own axis and its rotation around the sun both of which changes the predominant driving force for the atmosphere, solar radiation. Variability in solar radiation is not sinusoidal in nature, and the atmosphere is not linear in its response. Thus, any harmonics are a product of the non-sinusoidal shape of the daily and annual cycles of ozone (Valenzuela and Pontt, 2009). Parrish et al. (2016) finds that the annual and half- annual cycles are enough to characterise the seasonal variability of marine boundary layer $\mathrm{O}_{3}$, and that the forcing responsible for the half-annual cycle a priori is attributable to the 2nd harmonic of the photolysis rate of $\mathrm{O}_{3}$. It is important to note however, that the harmonics do not have to have independent physical forcings. The power of the harmonics can simply be a function of the mathematics.

For the surface ozone observational data set described in Sect. 4 (Sofen et al., 2016), we find almost all sites show significant peaks at the fundamentals (and most harmonics) of the annual and daily timescales. It is notable that we do not find any sites that show significance of a 7-day cycle (Altshuler et al., 1995; Marr and Harley, 2002; Beirle et al., 2003). Application of this approach to longer time series may also allow the investigation of other characteristic timescales such as North Atlantic Oscillation (NAO) or El Niño-Southern Oscillation (ENSO) (Ziemke et al., 2015).

\subsubsection{Definition of "seasonal" and "diurnal" cycles}

For all of the sites investigated the amplitude of the daily cycle is always significantly larger than any of its harmonics. However, this is not true for the annual cycle, as the magnitude of the half-annual cycle can sometimes compete with that of the annual cycle. To bring together the fundamental and the harmonics we superpose the fundamental and the harmonic signals to create "seasonal" and "diurnal" cycles. We show an example of this in Fig. 3, where the average, 1st (fundamental), 2nd, 3rd and 4th harmonics are superposed to create the net waveform. We choose to superpose down to the 12th harmonic for the diurnal cycle, and 4th harmonic for the seasonal cycle as they are the highest harmonics for each periodicity that we find significance ( $>99$ th percent confidence level). We characterise the superposed cycles with their amplitude being half the peak to trough height and their phase being the timing of the maxima. We modify the LSP code to ensure we estimate precisely at 1 day (and 2 nd to 12 th harmonics) and 365.25 days (and 2nd, 3rd and 4th harmonics) to ensure accurate estimation of these cycles. From this point onwards all references to the "seasonal" or "diurnal" cycle refer to the superposition of the respective fundamental and harmonics, and any "annual" and "daily" references refer to solely the fundamental terms.

\subsubsection{Fraction of total variance associated with a periodicity}

The significance of the diurnal or seasonal cycles varies by location. We can calculate the fractional variance $\left(\sigma^{2}\right)$ that both periodic waveforms contribute to the raw time series variance. We calculate this by extending both periodic waveforms to be the span of the raw time series, and take the fraction of the $\sigma^{2}$ of each waveform to the time series $\sigma^{2}$. Going further, superposing the extended diurnal and seasonal waveforms gives a periodic waveform repre- 


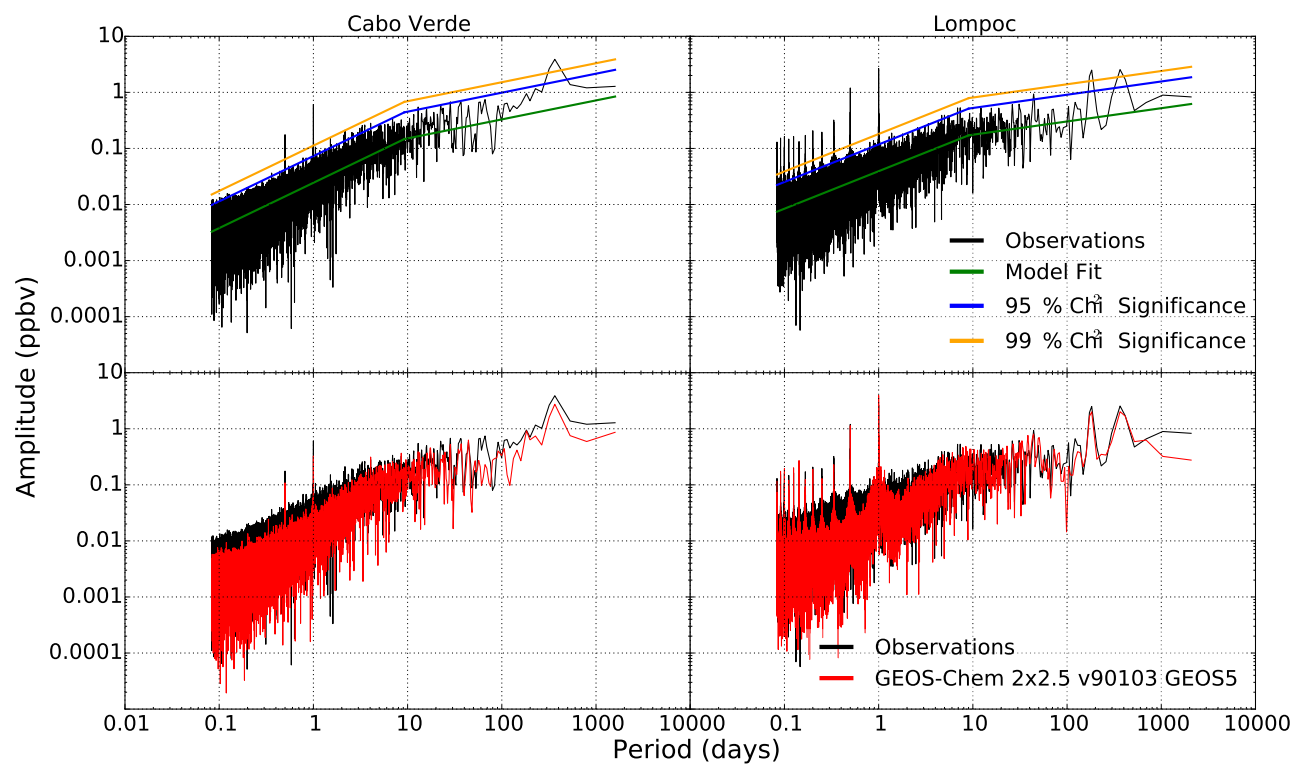

Figure 2. Lomb-Scargle periodogram spectra for surface $\mathrm{O}_{3}$ at Cabo Verde $\left(16.51^{\circ} \mathrm{N}, 24.52^{\circ} \mathrm{W}\right)$ and $\mathrm{Lompoc}\left(34.73^{\circ} \mathrm{N}, 120.43^{\circ} \mathrm{W}\right)$, between 2006 and 2012. The upper panels shows the observed data spectra together with chi-squared false-alarm levels for significant periodicity based on linear piecewise fits to the spectra. The lower panels compare the spectra of the observations (black) and the GEOSChem model (red).

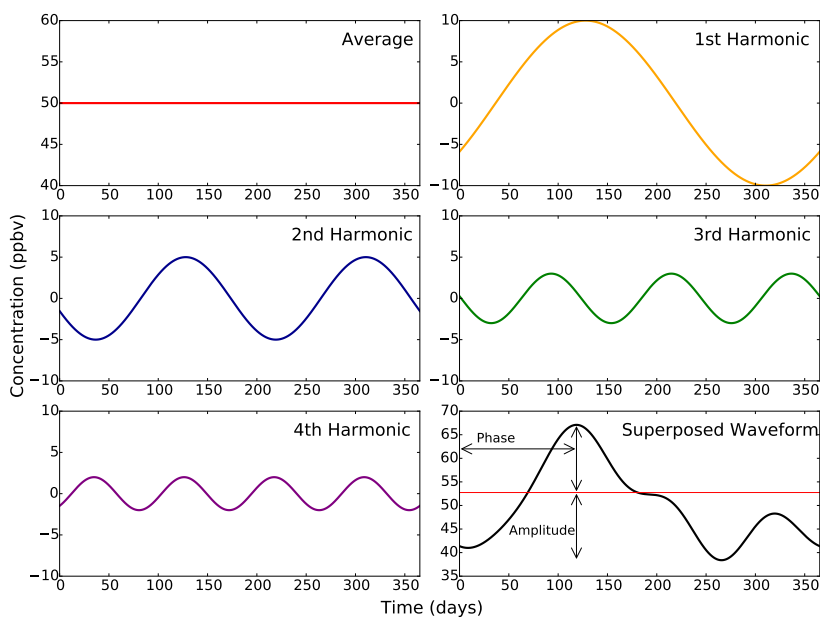

Figure 3. Example of spectral superposition of the average, fundamental frequency and the harmonics for a frequency of interest.

sentative of the total periodic $\sigma^{2}$. In the same way as it was previously done, we take the fraction of the total periodic $\sigma^{2}$ to the time series $\sigma^{2}$. Removing the total periodic waveform (including gaps) from the raw time series gives a time series that is solely derived of the weather and macroweather "noise". The variances of these periodic and noise time series are essentially additive so that $\sigma^{2}($ diurnal $)+\sigma^{2}$ (seasonal $)+\sigma^{2}($ noise $)=\sigma^{2}($ time series $)$.

\section{Application to observations}

We apply these methods to an updated hourly version of the long-term surface ozone data set from Sofen et al. (2016), compiled for the task of model evaluation. The data set applies multiple stringent data quality checks: removing urban sites, duplicate sites, coarse and partial year data, and obvious outliers. The data are originally drawn from the AirBase, CAPMON, CASTNET, EANET, EMEP, EPA AQS, NAPS, SEARCH, and WMO GAW monitoring networks (see Sofen et al. (2016) and references therein for details), and for simplicity we choose the period between 2005 and 2010 as this represents the most comprehensively observed time period. We exclude sites with data gaps of more than 365 days in this period and additionally sites with data gaps greater than 60 days in 3 or more years. We additionally limit the sites to be below $1.5 \mathrm{~km}$ from sea level. Figure 4 shows the location of the 710 valid sites. Most of the sites are from the US EPA AQS and EU AirBase data sets, which leads to an over representation of northern continental mid-latitude locations and an under representation of other areas of world.

We now investigate these observations in the context of the Lomb-Scargle-derived diurnal and seasonal cycles.

\subsection{Significance of seasonal and diurnal cycle}

Figure 5 shows the fraction of the variance at each site that is explained by the seasonal, diurnal, and the combined total periodic waveform. For most locations the seasonal cycle 


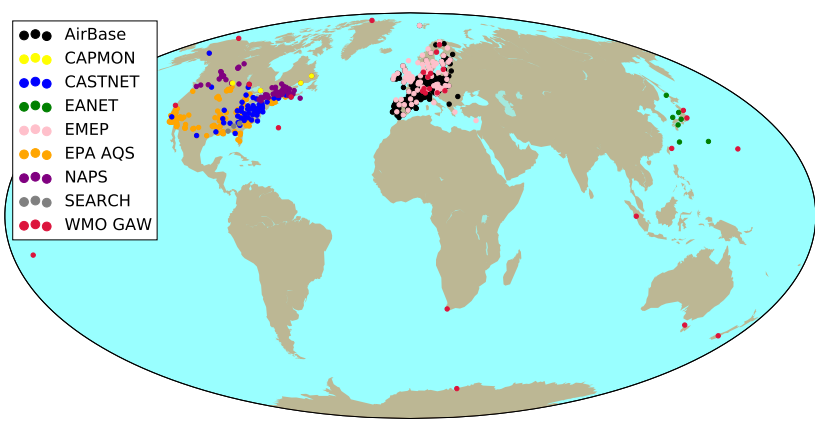

Figure 4. Map of surface sites reporting surface $\mathrm{O}_{3}$ between 2005 and 2010 used in this study, coloured by the providing data network.

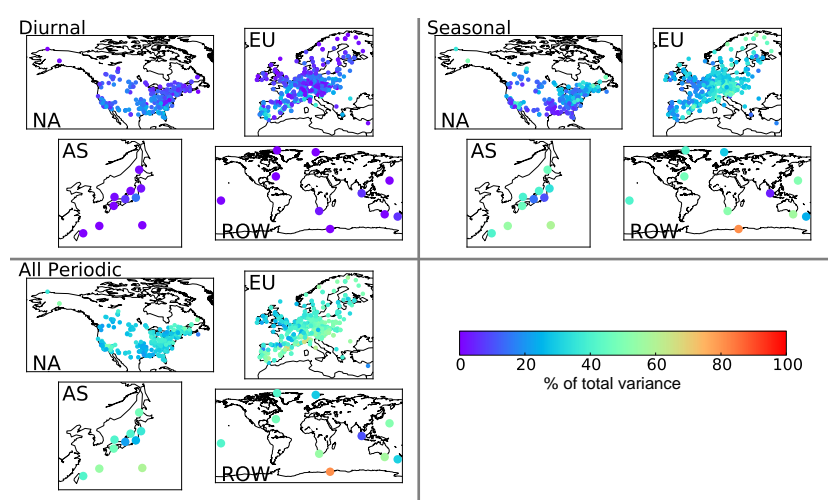

Figure 5. Observational fractional variance of time series by site from diurnal, seasonal and total periodicity. NA is North America, EU is Europe, AS is Asia, and ROW is rest of world.

represents a much larger fractional variance than the diurnal cycle.

The greatest contribution to total variance from the seasonal cycle is for the Antarctic site $(85 \%)$ and the oceanic and continental Southern Hemisphere (SH) sites (30-60\%). This reflects the lack of anthropogenic influence and spatial homogeneity of these regions leading to small spatial gradients in $\mathrm{O}_{3}$. Without spatial gradients to advect, weather systems cannot induce much variability, thus diurnal and seasonal variability dominates. For high $\mathrm{NO}_{x}$ regions in the north-eastern USA, southern and central Europe, and Japan (Fig. 13c), the seasonal cycle contributes $30-50 \%$ of the total variance. In southern central USA contribution from the seasonal cycle to the total variability is very small $(2-10 \%)$.

For the oceanic, polar, and sites in low $\mathrm{NO}_{x}$ areas in the extra-tropics (i.e. Cape Point $\left(34.21^{\circ} \mathrm{S}, 18.29^{\circ} \mathrm{E}\right)$ - the most south-westerly point of Africa) the diurnal cycle is negligible. These diurnal cycles are typically small as ozone production and loss in these low $\mathrm{NO}_{x}$ environments is small. However, it is a major contributor $(20-40 \%)$ to the total variability for some low latitude regions in North America and Europe, where high $\mathrm{NO}_{x}$ concentrations and photolysis rates lead to significant diurnal cycles.
Superposition of the diurnal and seasonal cycles gives a measure of the fraction of total variance induced from periodicity. For most sites the percentage contribution is between 40 and $60 \%$. The highest value being for the Antarctic site $(85 \%)$. The site with the lowest \% contribution from periodicity is in Indonesia (15\%), almost on the Equator, where there is very little variability in the solar radiation.

From this analysis it is evident that forcing of the atmosphere from seasonal and diurnal processes (changes in solar irradiation, chemistry, emissions, etc.) are for responsible for the most part for around $50 \%$ of the variability seen in these sites. The remaining $50 \%$ of the variability is attributable to changes on the weather or macroweather timescales due to processes such as boundary layer mixing, synoptic systems, changing emissions, etc. We now describe in more detail the seasonal and diurnal cycles seen at different locations.

\subsection{Seasonal cycle}

The seasonal cycle of ozone has been subject to much discussion (Derwent and Davies, 1994; Logan, 1985; Monks et al., 2000; Monks, 2000; Tanimoto et al., 2005; Cooper et al., 2010, 2014; Carpenter et al., 2010; Parrish et al., 2013; Clifton et al., 2014; Parrish et al., 2016). In general, NH midlatitude continental sites in the late 2000s show a springtime maxima, which has shifted from a broad summertime peak in the 1990s (Cooper et al., 2014). This change is strongly associated with $\mathrm{NO}_{x}$ emission reductions in Europe and North America due to air quality legislation (Parrish et al., 2013; Clifton et al., 2014); however, some of the most polluted urban sites still show a summertime peak (Cooper et al., 2014). Extra-tropical baseline sites show a consistent winter-spring maxima and tropical baseline sites a small winter maxima.

Our findings are consistent with the literature. The upper panels of Fig. 6 show the amplitude of the seasonal waveform for the observations. In general, most amplitudes are in the range of 5-15 ppbv. Sites influenced by highly polluted outflow such as the Central Valley in the USA and the Po Valley in Italy show large amplitudes (up to $22 \mathrm{ppbv}$ ). High amplitudes can also be seen in the Asian sites downwind of China, particularly to the south of Japan (up to $23 \mathrm{ppbv}$ ).

The maxima in the observed seasonal waveforms (upper panels of Fig. 7) occurs in the spring (April, May) for most of the continental sites with a tendency for later peaks in southern Europe. The small number of continental sites in the Southern Hemisphere (SH) show peaks 3-6 months out of phase compared to the Northern Hemisphere $(\mathrm{NH})$, peaking in the SH late winter to spring (August-October). The $\mathrm{SH}$ oceanic site, American Samoa $\left(14.27^{\circ} \mathrm{S}, 170.13^{\circ} \mathrm{W}\right)$, has a winter phase (July), whereas the two NH oceanic sites have springtime phases (March and April). This is suggestive that the lower pollution associated with the $\mathrm{SH}$ sites generally leads to an earlier seasonal peak in $\mathrm{O}_{3}$. 


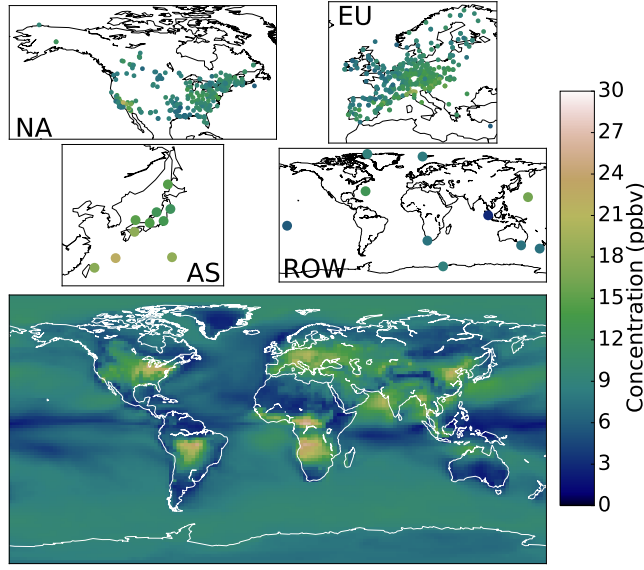

Figure 6. Seasonal amplitudes of observations (upper panels) and model (lower panel). NA is North America, EU is Europe, AS is Asia, and ROW is rest of world.

\subsection{Diurnal cycle}

The upper panels of Fig. 8 show the observational amplitudes of the diurnal cycle. In most of the locations this is in the range of $0-15 \mathrm{ppbv}$, with a tendency for larger amplitudes towards the tropics where solar radiation is more intense. There are also higher amplitudes in regions with higher $\mathrm{NO}_{x}$ emissions (Fig. 13c), with again the Central and Po valleys being evident.

Significant differences between sites can be seen in the phases of the diurnal cycle (upper panels of Fig. 9). Baseline sites (i.e. American Samoa) show a phase that peaks close to dawn, reflecting photochemical $\mathrm{O}_{3}$ destruction during the day and $\mathrm{O}_{3}$ build-up at night. Continental sites (i.e. Lompoc) show maxima in the early afternoon due to photochemical ozone production during the day.

The amplitude and phase of the diurnal and seasonal waveforms give a compact method of summarising much of the variability seen in surface ozone sites. We now explore how a CTM simulates these observations.

\section{Model perspective}

GEOS-Chem is a global three-dimensional (3-D) CTM driven by assimilated meteorological observations from the Goddard Earth Observing System (GEOS) of the NASA Global Modelling Assimilation Office (GMAO). The basic model is described in (Bey et al., 2001). We run version v9.01.03, using GEOS5 analysed meteorology at $2^{\circ} \times 2.5^{\circ}$ resolution run for 5 years between 2005 and 2010, outputting surface hourly $\mathrm{O}_{3}$ in each grid box. Global anthropogenic emissions of $\mathrm{CO}, \mathrm{NO}_{x}$, and $\mathrm{SO}_{2}$ are from the global EDGAR v3.2 inventory (Olivier et al., 2005). Global anthropogenic emissions of non-methane VOCs (NMVOCs) are from the RETRO monthly global inventory for the year 2000,

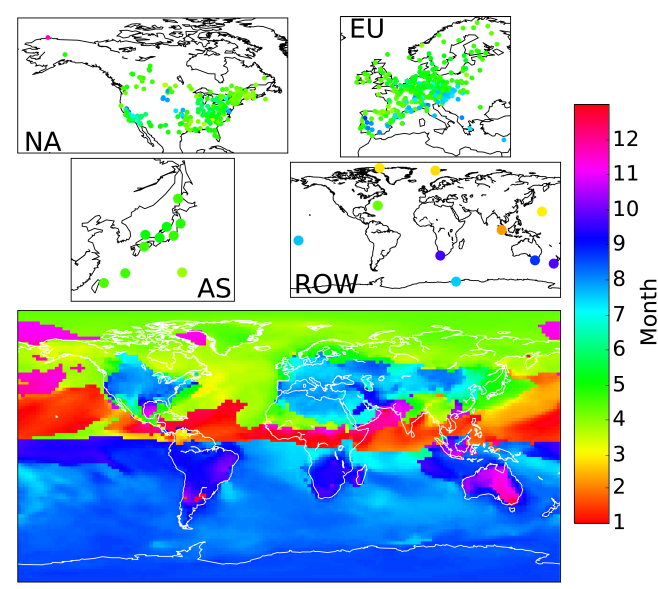

Figure 7. Seasonal phases of observations (upper panels) and model (lower panel). NA is North America, EU is Europe, AS is Asia, and ROW is rest of world.

as described by $\mathrm{Hu}$ et al. (2015), except for ethane (Xiao et al., 2008) and global biofuel emissions (Yevich and Logan, 2003). Inventories are scaled for individual years on the basis of economic data. Regional inventories are used in certain regions where there is improved information, as described by van Donkelaar et al. (2008). There are also inputs of $\mathrm{NO}_{x}$ from additional sources, i.e. aircraft (Wang et al., 1998), ships (Vinken et al., 2011), and biomass burning (Giglio et al., 2010). Inputs from lightning and soil $\mathrm{NO}_{x}$ are calculated online (Yienger and Levy, 1995; Murray et al., 2012). Biogenic VOC emissions are from the global MEGAN v2.1 inventory (also calculated online) (Guenther et al., 2006). Stratosphere-troposphere exchange is handled as a parameterised climatological representation of species sources and sinks (McLinden et al., 2000; Murray et al., 2012). Boundary layer mixing is parameterised using a non-local scheme, which considers different states of mixing within the boundary layer as determined by the static instability (Holtslag and Boville, 1993; Lin and McElroy, 2010).

\subsection{Modelled power spectrum}

The power spectra for the modelled surface $\mathrm{O}_{3}$ at Cabo Verde and Lompoc are shown in the lower panels of Fig. 2. As for the observed spectra the weather and macroweather regimes are visibly separated at around 10 days. The model underestimates the amplitude on the shortest timescales for both sites ( $<3$ days). This is unsurprising given the model spatial scale $\left(2^{\circ} \times 2.5^{\circ}\right.$, approx. $\left.250 \mathrm{~km}\right)$ and the timescale for model meteorological field updates ( 3 or $6 \mathrm{~h}$ ). As the timescale increases, the power in the model increases until it is comparable to that observed. This occurs at roughly 3 days. After this point the model appears to well simulate the power spectrum for both the weather and macroweather regimes. Thus, care needs to be taken in interpreting output of this model on timescales of less than around 3 days as much of the mete- 


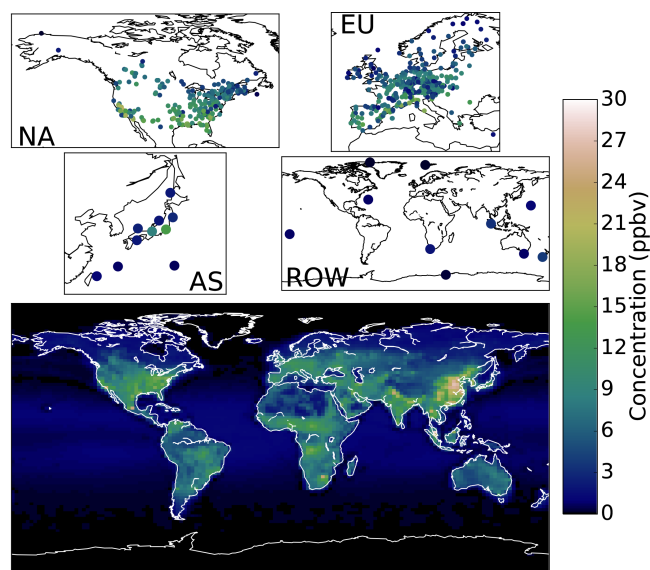

Figure 8. Diurnal amplitudes of observations (upper panels) and model (lower panel). NA is North America, EU is Europe, AS is Asia, and ROW is rest of world.

orological variability will be missing. In general this will be true for all models. Therefore, on some timescales the model cannot be expected to interpret the observed variability, and this limitation should be considered when preparing model experiments.

As with the observations there are peaks at 365.25 days and 1 day with appropriate harmonics. As per the observations, we superpose the daily and annual fundamentals with their harmonics to produce seasonal and diurnal signals, which we describe with a phase and amplitude. We now investigate the amplitude and phase of the modelled diurnal and seasonal cycles.

\subsection{Seasonal cycle}

The lowest panel of Fig. 6 shows the modelled amplitude for the seasonal cycle in surface ozone. As with the observations, the model shows large amplitudes over regions with significant anthropogenic $\mathrm{NO}_{x}$ emissions (Fig. 13c) such as North America, Europe, and Asia (up to $26 \mathrm{ppbv}$ ). Regions with significant seasonal cycles in the $\mathrm{NO}_{x}$ emissions, such as from biomass burning in the Amazon and Central Africa also have large cycles (up to $27 \mathrm{ppbv}$ ). These large amplitudes can be seen to extend away from the source regions into the Pacific and Indian oceans. Over the remote tropical oceans the seasonal cycle is very small (1 ppbv). Due to a scarcity of observations, many of these features are unobserved.

Figure 7 shows the global seasonal phase of modelled surface $\mathrm{O}_{3}$ (lower panel). There are distinct bands of phases. Over polluted $\mathrm{NH}$ continental regions a July-September maximum is calculated, with the cleaner northern extratropics showing a April-May maximum and the clean tropics a December-February maximum. In the SH there is a September-December maximum for continental regions, and a July-September maximum over the oceans and Antarctica.

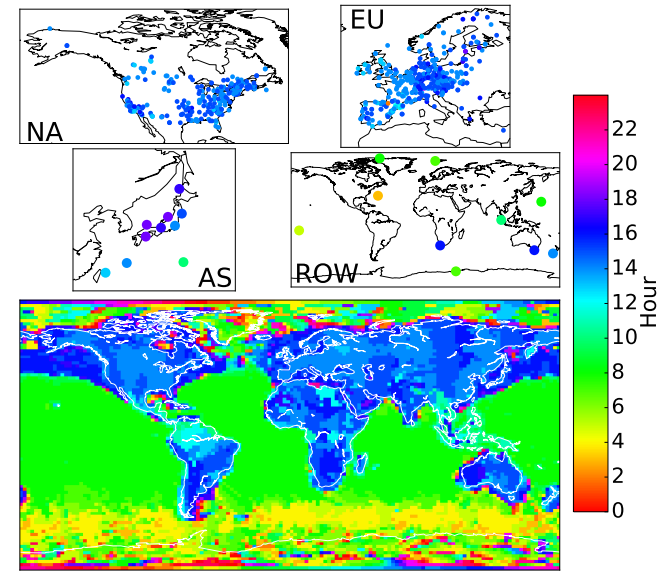

Figure 9. Diurnal phases of observations (upper panels) and model (lower panel). NA is North America, EU is Europe, AS is Asia, and ROW is rest of world.

\subsection{Diurnal cycle}

The largest diurnal amplitudes (lower panel of Fig. 8) are found in eastern China (up to $28 \mathrm{ppbv}$ ) where the emissions of $\mathrm{NO}_{x}$ are the greatest. This leads to large diurnal photochemical production of $\mathrm{O}_{3}$ but also large titration by $\mathrm{NO}$ at night. High diurnal amplitudes are also found over the polluted north-eastern USA (13-17 ppbv), central Europe (1013 ppbv), and India (11-15 ppbv). Again, regions with significant seasonal cycles in the $\mathrm{NO}_{x}$ emissions from biomass burning also have large amplitudes, i.e. Amazon, Indonesia, and Central Africa.

Figure 9 shows the global diurnal phases of modelled surface $\mathrm{O}_{3}$ (lower panel). As with the observations the two distinct clean and polluted regimes emerge. The polluted areas almost all have diurnal cycle peaking at 14:00 or 15:00 local solar time. This band includes all continental regions (except Greenland and polar regions). It also includes a band across the northern Pacific and northern Atlantic oceans. The clean areas almost all have a phase at 08:00, the exception being a circumpolar band of phases, which peak at 04:00 around Antarctica. The diurnal phase at the poles looks incoherent, which is predominantly due to the very small amplitudes in these regions; thus, the phase becomes practically irrelevant.

\section{Model - measurement comparisons}

The previous sections investigate the absolute amplitude and phase of the seasonal and diurnal cycle. In this section we use these parameters to investigate model performance against observations. 


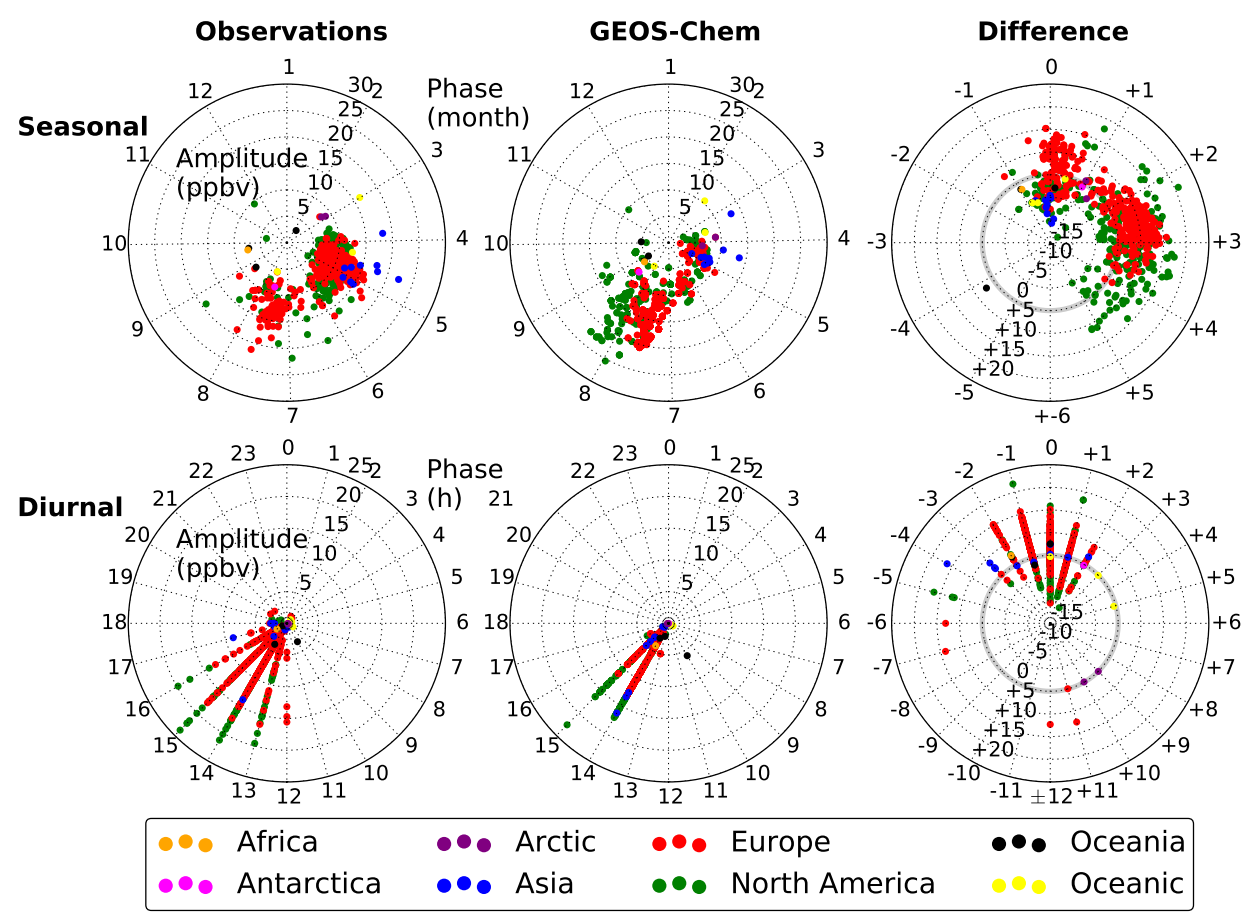

Figure 10. Polar plot of the diurnal and seasonal amplitudes and phases for observations and the GEOS-Chem model, and the differences between them. Circle colour indicates the location of the site.

\subsection{Seasonal cycle}

Figure 10 shows the polar representation of the seasonal cycle for the observations, model, and the difference between the two. North American and European site seasonal amplitudes are on average overestimated (up to $16 \mathrm{ppbv}$ ). The seasonal phase also shows biases with most sites' phases in North America and Europe peaking 1-5 months later than the observations, in mid-late summer rather than mid-late spring. Seasonal amplitudes for the African, Antarctic, Arctic, Asian, Oceania, and oceanic sites are all underestimated (up to $10 \mathrm{ppbv}$ ) but their phases show generally good agreement with the observations.

Figure 11 shows the spatial distribution of the difference for the seasonal amplitudes and phases. The biggest model overestimations for the amplitudes (upper panels) are in regions with high very $\mathrm{O}_{3}$ precursors, i.e. north-eastern USA (up to $16 \mathrm{ppbv}$ ) and mainland central Europe (to $11 \mathrm{ppbv}$ ); both generally at sites inland, away from oceanic influence. In contrast, it is the coastal and oceanic sites where the model underestimations are greatest, with the largest coming in Asia (5-10 ppbv) and eastern Canada (up to 8 ppbv).

The lower panels of Fig. 11 show that in mainland Europe the seasonal phases are generally 1-3 months too late in the model and 2-4 months too late in the north-eastern/southeastern USA. The biggest phase differences come in the central southern USA with the model phases approximately 45 months too late (a region where the seasonal cycle contributes very little to the total variance, Fig. 5).

\subsection{Diurnal cycle}

Figure 10 also shows the polar representation of the diurnal cycle observations, model, and difference. The model has some skill in determining the diurnal amplitudes. There is on average an overestimation of North American, European, and Asian diurnal amplitudes (up to $17 \mathrm{ppbv}$ ). Amplitudes for the clean oceanic sites are well estimated, with the rest of the sites in Oceania, Africa, Antarctic, and Arctic displaying reasonable agreement. The model has generally good skill for simulating the diurnal phases (ignoring the polar sites); however, notable biases show that in the oceanic and Asian sites with the model up to $5 \mathrm{~h}$ late, and up $4 \mathrm{~h}$ early respectively for the groupings. Additionally for the North American and European groupings, the model simulates the vast majority of phases in a narrow band, where there is a broader grouping of phases in the observations. This may represent issues with the timing of processes such as boundary layer mixing, which is suggested to be excessive (Travis et al., 2016).

Spatially, Fig. 12 upper panels, the biggest overestimations in the amplitudes are again in regions with high emissions of $\mathrm{O}_{3}$ precursors: Central Valley USA (up to $17 \mathrm{ppbv}$ ), northeastern USA (up to $14 \mathrm{ppbv}$ ), Japan (up to $11 \mathrm{ppbv}$ ), and mainland central Europe (up to $11 \mathrm{ppbv}$ ). The biggest underestimations come in coastal regions, i.e. US west coast (up to $11 \mathrm{ppbv}$ ) and southern Europe (up to $10 \mathrm{ppbv}$ ).

The lower panels of Fig. 12 show the model in the high $\mathrm{NO}_{x}$ emitting regions of north-eastern USA and central Europe to have too early a phase also ( -1 to $2 \mathrm{~h}$ ). The largest 


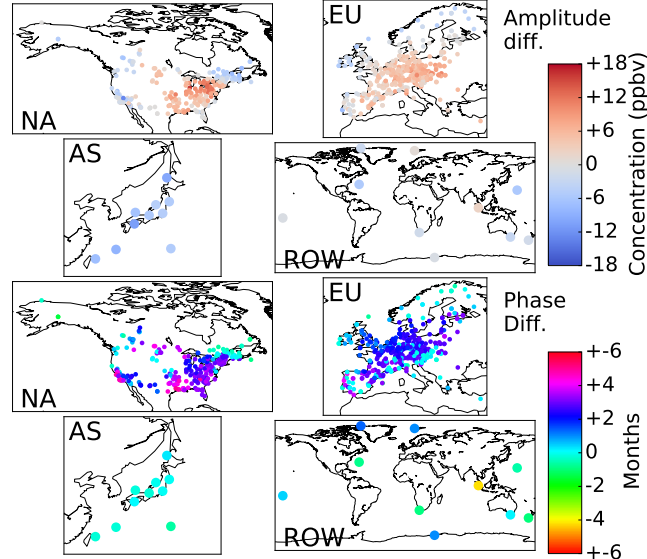

Figure 11. Seasonal amplitude (upper panel) and phase (lower panel) differences between observations and the GEOS-Chem model. NA is North America, EU is Europe, AS is Asia, and ROW is rest of world.

phase offsets (excluding polar sites) are found in the oceanic sites of Bermuda and American Samoa $(+3$ and $+5 \mathrm{~h})$.

\subsection{Possible causes of biases}

A range of model biases are evident in this analysis. These may be explained by a range of model errors/uncertainties in the emissions, deposition, chemistry, photolysis rates, boundary layer mixing, stratospheric transport, tropospheric transport, resolution, etc.

The most discussed uncertainties lie in the emissions. Probably the most accurate emission estimates are for North America and Europe, but even here significant uncertainties exist. Anderson et al. (2014) found the anthropogenic US National Emissions Inventory (NEI) $2005 \mathrm{NO}_{x}$ emissions (projected to 2011) in the mid-eastern USA to be 51$70 \%$ too high compared with measurements taken on the DISCOVER-AQ field campaign. The NEI 2011 emissions appear to overestimated by an even larger margin. Vestreng et al. (2009) found $\pm 8-25 \%$ uncertainties in European $\mathrm{NO}_{x}$ emissions. Stein et al. (2014) also recently found wintertime systematic underestimates in NH CO by a global CTM, best offset by increases in winter $\mathrm{CO}$ road traffic emissions together with an improved $\mathrm{CO}$ dry deposition scheme.

As anthropogenic $\mathrm{NO}_{x}$ decreases, the relative importance of lightning and soil $\mathrm{NO}_{x}$ is much greater and the importance of low $\mathrm{NO}_{x}$ isoprene chemistry increases (Palmer, 2003; Fiore et al., 2014). Millet et al. (2008) showed the MEGAN v2.1 biogenic emission inventory in the USA (Guenther et al., 2006) overestimates emissions of isoprene in areas where it specifies high emission factors.

Reduced winter/early spring photochemical removal by NO titration (Jonson et al., 2006); efficient transport of enhanced springtime $\mathrm{O}_{3}$ from East Asia (Wild and Akimoto, 2001; Tanimoto, 2002; Tanimoto et al., 2005); as well as ear-

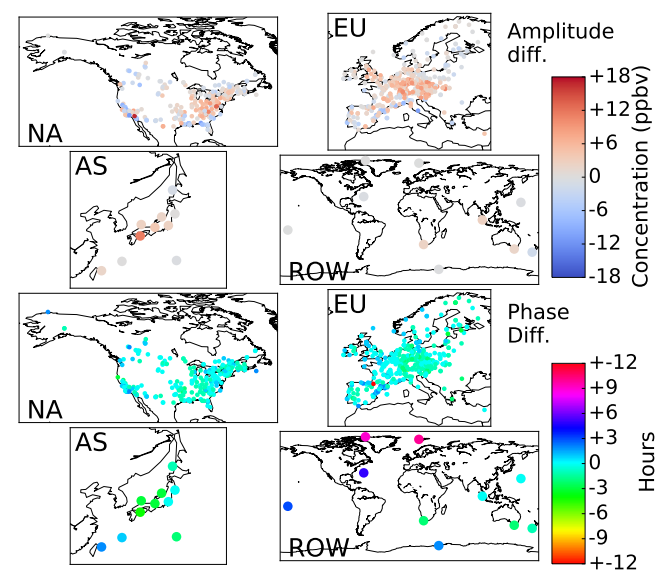

Figure 12. Diurnal amplitude (upper panel) and phase (lower panel) differences between observations and the GEOS-Chem model. NA is North America, EU is Europe, AS is Asia, and ROW is rest of world.
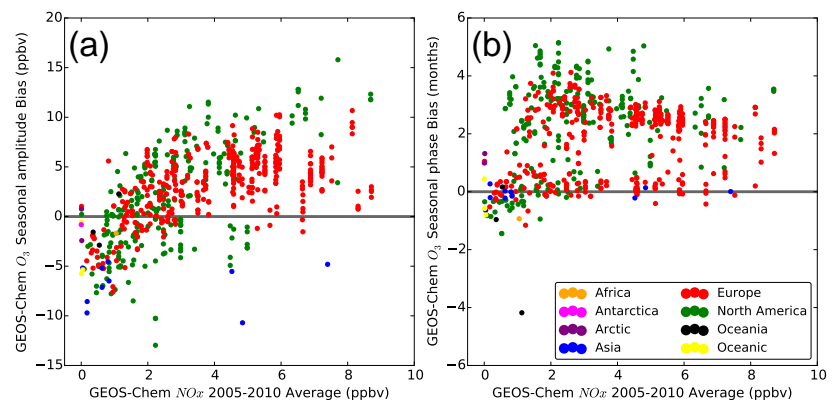

(c)
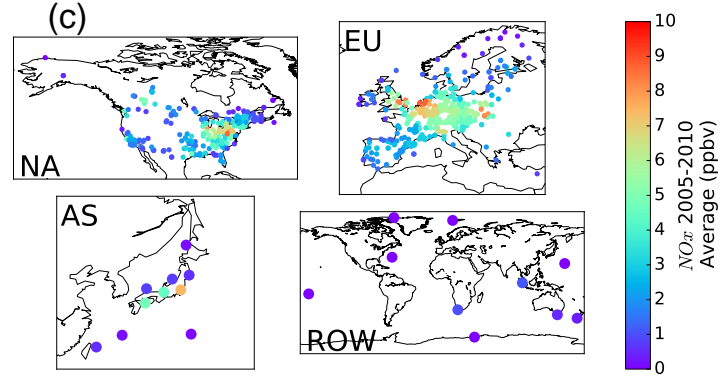

Figure 13. (a) Seasonal amplitude bias vs. 2005-2010 Average GEOS-Chem model $\mathrm{NO}_{x}$, (b) Seasonal phase bias vs. 2005-2010 Average GEOS-Chem model $\mathrm{NO}_{x}$, (c) 2005-2010 Average GEOSChem model $\mathrm{NO}_{x}$ by observational site. NA is North America, EU is Europe, AS is Asia, and ROW is rest of world.

lier peak stratospheric-tropospheric exchange to the surface, may be synergistic factors along with reduced emissions in bringing about a springtime ozone maximum for $\mathrm{NH}$ midlatitude continental sites (Parrish et al., 2013).

We attempt to correlate seasonal model $\mathrm{O}_{3}$ amplitude and phase biases with average 2005-2010 model $\mathrm{NO}_{x}$, Fig. 13. For the seasonal cycle the greatest overestimates of the amplitude generally correlate with the highest $\mathrm{NO}_{x}$ concentrations in the model (panel a); however, this is not true for the 
largest biases in the phase (panel b). Although the phase biases are not linear with $\mathrm{NO}_{x}$ emissions, from the amplitude biases it is clear that evaluation of $\mathrm{NO}_{x}$ emissions would be a sensible place to start in trying to correct biases.

\section{Conclusions}

We have used a Lomb-Scargle methodology to spectrally analyse surface ozone. We find spectra with distinct relationships between amplitude and period due to meteorological processes (weather and macroweather) as well as peaks at 1and 365.25-day timescales (and harmonics). The amplitude and phase of the periodicity associated with these timescales varies significantly between sites.

A comparison between model output and measured surface ozone spectra shows a model underestimate of the amplitudes at high frequencies due the spatial and temporal scales inherent in the model.

A comparison between of the periodic components for model and measurements shows model biases in the seasonal cycle in the mid-latitude $\mathrm{NH}$, where there is a general overestimation of the seasonal amplitudes in North America and Europe of up to $16 \mathrm{ppbv}$, together with delayed phase maxima by $1-5$ months. We show the amplitude biases may be related to errors in the emissions of $\mathrm{NO}_{x}$. We find lower biases for the diurnal cycle but show the majority of amplitudes in Europe and North America to be overestimated, by up to 17 ppbv.

This methodology has significant scope for future use. It can be applied to a range of model-measurement applications and the associated metrics are highly suitable for Multimodel Intercomparison Projects (MIPs). We aim to apply this methodology to the Atmospheric Chemistry and Climate Model Intercomparison Project (ACCMIP) and ChemistryClimate Model Initiative (CCMI) MIPs to explore differences in chemistry between the different CTMs/ESMs.

\section{Data availability}

Observational data used in this work is publicly available in a gridded format (to protect the data ownership rights of the original data contributors) at $1^{\circ}$ resolution, as well as other common model resolutions (e.g. $2^{\circ} \times 2.5^{\circ}$ ) in netCDF-4 file format via the British Atmospheric Data Centre (BADC) (doi:10.5285/08fbe63d-fa6d4a7a-b952-5932e3ab0452) (Evans and Sofen, 2015; Sofen et al., 2016).

The GEOS-Chem CTM is an open-access model, the source code can be downloaded from http://acmg.seas. harvard.edu/geos/. Specific model data used in this work are available on request, please contact:db876@york.ac.uk or mat.evans@york.ac.uk.
Acknowledgements. This work was funded by the NERC BACCHUS and CAST projects NE/L01291X/1, NE/J006165/1. Thanks go to the data providers at the AirBase, CAPMON, CASTNET, EANET, EMEP, EPA AQS, NAPS, SEARCH, and WMO GAW monitoring networks for the data to make this evaluation possible. Thanks also go to colleagues at the Wolfson Atmospheric Chemistry Laboratories, University of York for the maintaining of the monitoring station in Cabo Verde, providing data for this paper.

Edited by: R. Harley

\section{References}

Altshuler, S., Arcado, T., and Lawson, D.: Weekday vs. weekend ambient ozone concentrations - discussion and hypotheses with focus on northern California, J. Air Waste Manage., 45, 967-972, doi:10.1080/10473289.1995.10467428, 1995.

Anderson, D. C., Loughner, C. P., Diskin, G., Weinheimer, A., Canty, T. P., Salawitch, R. J., Worden, H. M., Fried, A., Mikoviny, T., Wisthaler, A., and Dickerson, R. R.: Measured and modeled $\mathrm{CO}$ and $\mathrm{NO}_{y}$ in DISCOVER-AQ: An evaluation of emissions and chemistry over the eastern US, Atmos. Environ. 96, 78-87, doi:10.1016/j.atmosenv.2014.07.004, 2014.

Beirle, S., Platt, U., Wenig, M., and Wagner, T.: Weekly cycle of $\mathrm{NO}_{2}$ by GOME measurements: a signature of anthropogenic sources, Atmos. Chem. Phys., 3, 2225-2232, doi:10.5194/acp3-2225-2003, 2003.

Bey, I., Jacob, D. J., Yantosca, R. M., Logan, J. A., Field, B. D., Fiore, A. M., Li, Q. B., Liu, H. G. Y., Mickley, L. J., and Schultz, M. G.: Global modeling of tropospheric chemistry with assimilated meteorology: Model description and evaluation, J. Geophys. Res.-Atmos., 106, 23073-23095, doi:10.1029/2001jd000807, 2001.

Carpenter, L. J., Fleming, Z. L., Read, K. A., Lee, J. D., Moller, S. J., Hopkins, J. R., Purvis, R. M., Lewis, A. C., Muller, K., Heinold, B., Herrmann, H., Fomba, K. W., van Pinxteren, D., Muller, C., Tegen, I., Wiedensohler, A., Muller, T., Niedermeier, N., Achterberg, E. P., Patey, M. D., Kozlova, E. A., Heimann, M., Heard, D. E., Plane, J. M. C., Mahajan, A., Oetjen, H., Ingham, T., Stone, D., Whalley, L. K., Evans, M. J., Pilling, M. J., Leigh, R. J., Monks, P. S., Karunaharan, A., Vaughan, S., Arnold, S. R., Tschritter, J., Pohler, D., Friess, U., Holla, R., Mendes, L. M., Lopez, H., Faria, B., Manning, A. J., and Wallace, D. W. R.: Seasonal characteristics of tropical marine boundary layer air measured at the Cape Verde Atmospheric Observatory, J. Atmos. Chem., 67, 87-140, doi:10.1007/s10874-011-9206-1, 2010.

Clifton, O. E., Fiore, A. M., Correa, G., Horowitz, L. W., and Naik, V.: Twenty-first century reversal of the surface ozone seasonal cycle over the northeastern United States, Geophys. Res. Lett., 41, 7343-7350, doi:10.1002/2014GL061378, 2014.

Cooper, O. R., Parrish, D. D., Stohl, A., Trainer, M., Nédélec, P., Thouret, V., Cammas, J. P., Oltmans, S. J., Johnson, B. J., Tarasick, D., Leblanc, T., McDermid, I. S., Jaffe, D., Gao, R., Stith, J., Ryerson, T., Aikin, K., Campos, T., Weinheimer, A., and Avery, M. A.: Increasing springtime ozone mixing ratios in the free troposphere over western North America, Nature, 463, 344-348, doi:10.1038/nature08708, 2010. 
Cooper, O. R., Gao, R.-S., Tarasick, D., Leblanc, T., and Sweeney, C.: Long-term ozone trends at rural ozone monitoring sites across the United States, 1990-2010, J. Geophys. Res.-Atmos., 117, D22307, doi:10.1029/2012JD018261, 2012.

Cooper, O. R., Parrish, D. D., Ziemke, J., Balashov, N. V., Cupeiro, M., Galbally, I. E., Gilge, S., Horowitz, L., Jensen, N. R., Lamarque, J.-F., Naik, V., Oltmans, S. J., Schwab, J., Shindell, D. T., Thompson, A. M., Thouret, V., Wang, Y., and Zbinden, R. M.: Global distribution and trends of tropospheric ozone: An observation-based review, Elem. Sci. Anthr., 2, 000029, doi:10.12952/journal.elementa.000029, 2014.

Derwent, R. and Davies, T.: Modelling the impact of $\mathrm{NO}_{x}$ or hydrocarbon control on photochemical ozone in Europe, Atmos. Environ., 28, 2039-2052, doi:10.1016/1352-2310(94)90472-3, 1994.

Derwent, R., Stevenson, D., Doherty, R., Collins, W., and Sanderson, M.: How is surface ozone in Europe linked to Asian and North American $\mathrm{NO}_{x}$ emissions?, Atmos. Environ., 42, 74127422, doi:10.1016/j.atmosenv.2008.06.037, 2008.

Dutton, S. J., Rajagopalan, B., Vedal, S., and Hannigan, M. P.: Temporal patterns in daily measurements of inorganic and organic speciated $\mathrm{PM}_{2.5}$ in Denver, Atmos. Environ., 44, 987-998, doi:10.1016/j.atmosenv.2009.06.006, 2010.

Ehhalt, D. H.: Photooxidation of trace gases in the troposphere, Phys. Chem. Chem. Phys., 1, 5401-5408, doi:10.1039/a905097c, 1999.

Evans, M. J. and Sofen, E. D.: Gridded Global Surface Ozone Metrics data (1971-2015) for Atmospheric Chemistry Model Evaluation - version 2.4, Centre for Environmental Data Analysis, doi:10.5285/08fbe63d-fa6d-4a7a-b952-5932e3ab0452, 2015.

Fiore, A., Oberman, J., Lin, M., Zhang, L., Clifton, O., Jacob, D., Naik, V., Horowitz, L., Pinto, J., and Milly, G.: Estimating North American background ozone in U.S. surface air with two independent global models: Variability, uncertainties, and recommendations, Atmos. Environ., 96, 284-300, doi:10.1016/j.atmosenv.2014.07.045, 2014.

Forster, P., Ramaswamy, V., Artaxo, P., Berntsen, T., Betts, R., Fahey, D. W., Haywood, J., Lean, J., Lowe, D. C., Myhre, G., Nganga, J., Prinn, R., Raga, G., Schulz, M., and Dorland, R. V.: Changes in Atmospheric Constituents and in Radiative Forcing, in: Climate Change 2007: The Physical Science Basis. Contribution of Working Group I to the Fourth Assessment Report of the Intergovernmental Panel on Climate Change, edited by: Solomon, S., Qin, D., Manning, M., Chen, Z., Marquis, M., Averyt, K., Tignor, M., and Miller, H., 131-215, Cambridge University Press, Cambridge, UK, 2007.

Fowler, D., Pilegaard, K., Sutton, M., Ambus, P., Raivonen, M., Duyzer, J., Simpson, D., Fagerli, H., Fuzzi, S., Schjoerring, J., Granier, C., Neftel, A., Isaksen, I., Laj, P., Maione, M., Monks, P., Burkhardt, J., Daemmgen, U., Neirynck, J., Personne, E., Wichink-Kruit, R., Butterbach-Bahl, K., Flechard, C., Tuovinen, J., Coyle, M., Gerosa, G., Loubet, B., Altimir, N., Gruenhage, L., Ammann, C., Cieslik, S., Paoletti, E., Mikkelsen, T., Ro-Poulsen, H., Cellier, P., Cape, J., Horváth, L., Loreto, F., Niinemets, Ü., Palmer, P., Rinne, J., Misztal, P., Nemitz, E., Nilsson, D., Pryor, S., Gallagher, M., Vesala, T., Skiba, U., Brüggemann, N., Zechmeister-Boltenstern, S., Williams, J., O’Dowd, C., Facchini, M., de Leeuw, G., Flossman, A., Chaumerliac, N., and Erisman, J.: Atmospheric composition change: Ecosystems-Atmosphere interactions, Atmos. Environ., 43, 5193-5267, doi:10.1016/j.atmosenv.2009.07.068, 2009.

Giglio, L., Randerson, J. T., van der Werf, G. R., Kasibhatla, P. S., Collatz, G. J., Morton, D. C., and DeFries, R. S.: Assessing variability and long-term trends in burned area by merging multiple satellite fire products, Biogeosciences, 7, 1171-1186, doi:10.5194/bg-7-1171-2010, 2010.

Guenther, A., Karl, T., Harley, P., Wiedinmyer, C., Palmer, P. I., and Geron, C.: Estimates of global terrestrial isoprene emissions using MEGAN (Model of Emissions of Gases and Aerosols from Nature), Atmos. Chem. Phys., 6, 3181-3210, doi:10.5194/acp-63181-2006, 2006.

Harris, F.: On the use of windows for harmonic analysis with the discrete Fourier transform, in: Proc. IEEE, Vol. 66, 5183, Institute of Electrical and Electronics Engineers (IEEE), doi:10.1109/PROC.1978.10837, 1978.

Hess, P. G. and Zbinden, R.: Stratospheric impact on tropospheric ozone variability and trends: 1990-2009, Atmos. Chem. Phys., 13, 649-674, doi:10.5194/acp-13-649-2013, 2013.

Hocke, K.: Phase estimation with the Lomb-Scargle periodogram method, Ann. Geophys., 16, 356-358, 1998.

Holtslag, A. A. M. and Boville, B. A.: Local versus nonlocal boundary layer diffusion in a global climate model, J. Climate, 6, 1825-1842, doi:10.1175/15200442(1993)006<1825:LVNBLD>2.0.CO;2, 1993.

Horne, J. H. and Baliunas, S. L.: A prescription for period analysis of unevenly sampled time-series, Astrophys. J., 302, 757-763, doi:10.1086/164037, 1986.

Hu, L., Millet, D. B., Baasandorj, M., Griffis, T. J., Travis, K. R., Tessum, C. W., Marshall, J. D., Reinhart, W. F., Mikoviny, T., Müller, M., Wisthaler, A., Graus, M., Warneke, C., and de Gouw, J.: Emissions of C6-C8 aromatic compounds in the United States: Constraints from tall tower and aircraft measurements, J. Geophys. Res.-Atmos., 120, 826-842, doi:10.1002/2014JD022627, 2015.

Jenkin, M. E. and Clemitshaw, K. C.: Ozone and other secondary photochemical pollutants: chemical processes governing their formation in the planetary boundary layer, Atmos. Environ., 34, 2499-2527, doi:10.1016/S1352-2310(99)00478-1, 2000.

Jonson, J. E., Simpson, D., Fagerli, H., and Solberg, S.: Can we explain the trends in European ozone levels?, Atmos. Chem. Phys., 6, 51-66, doi:10.5194/acp-6-51-2006, 2006.

Levy, H.: Photochemistry of the lower troposphere, Planet. Space Sci., 20, 919-935, doi:10.1016/0032-0633(72)90177-8, 1972.

Lin, J.-T. and McElroy, M. B.: Impacts of boundary layer mixing on pollutant vertical profiles in the lower troposphere: Implications to satellite remote sensing, Atmos. Environ., 44, 17261739, doi:10.1016/j.atmosenv.2010.02.009, 2010.

Logan, J. A.: Tropospheric ozone: Seasonal behavior, trends, and anthropogenic influence, J. Geophys. Res., 90, 10463, doi:10.1029/JD090iD06p10463, 1985.

Logan, J. A., Staehelin, J., Megretskaia, I. A., Cammas, J.-P., Thouret, V., Claude, H., De Backer, H., Steinbacher, M., Scheel, H.-E., Stübi, R., Fröhlich, M., and Derwent, R.: Changes in ozone over Europe: Analysis of ozone measurements from sondes, regular aircraft (MOZAIC) and alpine surface sites, J. Geophys. Res., 117, D09301, doi:10.1029/2011JD016952, 2012. 
Lomb, N. R.: Least-squares frequency-analysis of unequally spaced data, Astrophys. Space Sci., 39, 447-462, doi:10.1007/bf00648343, 1976.

Lovejoy, S. and Schertzer, D.: Low-Frequency Weather and the Emergence of the Climate, in: Extrem. Events Nat. Hazards Complex. Perspect., 231-254, American Geophysical Union, doi:10.1029/2011GM001087, 2013a.

Lovejoy, S. and Schertzer, D.: The Weather and Climate: Emergent Laws and Multifractal Cascades, Cambridge University Press, Cambridge, UK, 2013b.

Marr, L. C. and Harley, R. A.: Spectral analysis of weekdayweekend differences in ambient ozone, nitrogen oxide, and nonmethane hydrocarbon time series in California, Atmos. Environ., 36, 2327-2335, doi:10.1016/S1352-2310(02)00188-7, 2002.

McLinden, C. A., Olsen, S. C., Hannegan, B., Wild, O., Prather, M. J., and Sundet, J.: Stratospheric ozone in 3-D models: A simple chemistry and the cross-tropopause flux, J. Geophys. Res., 105, 14653, doi:10.1029/2000JD900124, 2000.

Millet, D. B., Jacob, D. J., Boersma, K. F., Fu, T.-M., Kurosu, T. P., Chance, K., Heald, C. L., and Guenther, A.: Spatial distribution of isoprene emissions from North America derived from formaldehyde column measurements by the OMI satellite sensor, J. Geophys. Res., 113, D02307, doi:10.1029/2007JD008950, 2008.

Monks, P. S.: A review of the observations and origins of the spring ozone maximum, Atmos. Environ., 34, 3545-3561, doi:10.1016/s1352-2310(00)00129-1, 2000.

Monks, P. S.: Gas-phase radical chemistry in the troposphere, Chem. Soc. Rev., 34, 376-95, doi:10.1039/b307982c, 2005.

Monks, P. S., Salisbury, G., Holland, G., Penkett, S. A., and Ayers, G. P.: A seasonal comparison of ozone photochemistry in the remote marine boundary layer, Atmos. Environ., 34, 2547-2561, doi:10.1016/S1352-2310(99)00504-X, 2000.

Monks, P. S., Archibald, A. T., Colette, A., Cooper, O., Coyle, M., Derwent, R., Fowler, D., Granier, C., Law, K. S., Mills, G. E., Stevenson, D. S., Tarasova, O., Thouret, V., von Schneidemesser, E., Sommariva, R., Wild, O., and Williams, M. L.: Tropospheric ozone and its precursors from the urban to the global scale from air quality to short-lived climate forcer, Atmos. Chem. Phys., 15, 8889-8973, doi:10.5194/acp-15-8889-2015, 2015.

Murray, L. T., Jacob, D. J., Logan, J. A., Hudman, R. C., and Koshak, W. J.: Optimized regional and interannual variability of lightning in a global chemical transport model constrained by LIS/OTD satellite data, J. Geophys. Res.-Atmos., 117, D20307, doi:10.1029/2012JD017934, 2012.

Musial, J. P., Verstraete, M. M., and Gobron, N.: Technical Note: Comparing the effectiveness of recent algorithms to fill and smooth incomplete and noisy time series, Atmos. Chem. Phys., 11, 7905-7923, doi:10.5194/acp-11-7905-2011, 2011.

Olivier, J., Aardenne, J. A, Dentener, F., Ganzeveld, L., and Peters, J.: Recent trends in global greenhouse gas emissions: regional trends and spatial distribution of key sources, Environ. Sci., 2, 81-99, doi:10.1080/15693430500400345, 2005.

Oltmans, S. J., Lefohn, A. S., Harris, J. M., Galbally, I., Scheel, H. E., Bodeker, G., Brunke, E., Claude, H., Tarasick, D., Johnson, B. J., Simmonds, P., Shadwick, D., Anlauf, K., Hayden, K., Schmidlin, F., Fujimoto, T., Akagi, K., Meyer, C., Nichol, S., Davies, J., Redondas, A., and Cuevas, E.: Long-term changes in tropospheric ozone, Atmos. Environ., 40, 3156-3173, doi:10.1016/j.atmosenv.2006.01.029, 2006.

Oltmans, S. J., Lefohn, A. S., Shadwick, D., Harris, J. M., Scheel, H. E., Galbally, I., Tarasick, D. W., Johnson, B. J., Brunke, E. G., Claude, H., Zeng, G., Nichol, S., Schmidlin, F., Davies, J., Cuevas, E., Redondas, A., Naoe, H., Nakano, T., and Kawasato, T.: Recent tropospheric ozone changes - A pattern dominated by slow or no growth, Atmos. Environ., 67, 331-351, doi:10.1016/j.atmosenv.2012.10.057, 2013.

Palmer, P. I.: Mapping isoprene emissions over North America using formaldehyde column observations from space, J. Geophys. Res., 108, 4180, doi:10.1029/2002JD002153, 2003.

Parrish, D. D., Law, K. S., Staehelin, J., Derwent, R., Cooper, O. R., Tanimoto, H., Volz-Thomas, A., Gilge, S., Scheel, H. E., Steinbacher, M., and Chan, E.: Lower tropospheric ozone at northern midlatitudes: Changing seasonal cycle, Geophys. Res. Lett., 40, 1631-1636, doi:10.1002/grl.50303, 2013.

Parrish, D. D., Lamarque, J.-F., Naik, V., Horowitz, L., Shindell, D. T., Staehelin, J., Derwent, R., Cooper, O. R., Tanimoto, H., Volz-Thomas, A., Gilge, S., Scheel, H.-E., Steinbacher, M., and Fröhlich, M.: Long-term changes in lower tropospheric baseline ozone concentrations: Comparing chemistry-climate models and observations at northern midlatitudes, J. Geophys. Res.-Atmos., 119, 5719-5736, doi:10.1002/2013JD021435, 2014.

Parrish, D. D., Galbally, I. E., Lamarque, J.-F., Naik, V., Horowitz, L., Shindell, D. T., Oltmans, S. J., Derwent, R., Tanimoto, H., Labuschagne, C., and Cupeiro, M.: Seasonal cycles of $\mathrm{O}_{3}$ in the marine boundary layer: Observation and model simulation comparisons, J. Geophys. Res.-Atmos., 121, 538-557, doi:10.1002/2015JD024101, 2016.

Press, W. H. and Rybicki, G. B.: Fast algorithm for spectralanalysis of unevenly sampled data, Astrophys. J., 338, 277-280, doi:10.1086/167197, 1989.

Press, W. H., Teukolsky, S. A., Vetterling, W. T., and Flannery, B. P.: Numerical Recipes in Fortran 77 - The Art Of Scientific Computing - Volume I, Vol. 1, Cambridge University Press, doi:10.1016/0169-2607(87)90037-X, 1992.

Rehfeld, K., Marwan, N., Heitzig, J., and Kurths, J.: Comparison of correlation analysis techniques for irregularly sampled time series, Nonlin. Processes Geophys., 18, 389-404, doi:10.5194/npg18-389-2011, 2011.

Scargle, J. D.: Studies in astronomical time-series analysis .2. Statistical aspects of spectral-analysis of unevenly spaced data, Astrophys. J., 263, 835-853, doi:10.1086/160554, 1982.

Schnell, J. L., Prather, M. J., Josse, B., Naik, V., Horowitz, L. W., Cameron-Smith, P., Bergmann, D., Zeng, G., Plummer, D. A., Sudo, K., Nagashima, T., Shindell, D. T., Faluvegi, G., and Strode, S. A.: Use of North American and European air quality networks to evaluate global chemistry-climate modeling of surface ozone, Atmos. Chem. Phys., 15, 10581-10596, doi:10.5194/acp-15-10581-2015, 2015.

Schulz, M. and Mudelsee, M.: REDFIT: estimating red-noise spectra directly from unevenly spaced paleoclimatic time series, Comput. Geosci., 28, 421-426, doi:10.1016/s00983004(01)00044-9, 2002.

Schulz, M. and Stattegger, K.: SPECTRUM: Spectral analysis of unevenly spaced paleoclimatic time series, Comput. Geosci., 23, 929-945, doi:10.1016/s0098-3004(97)00087-3, 1997. 
Sofen, E. D., Bowdalo, D., Evans, M. J., Apadula, F., Bonasoni, P., Cupeiro, M., Ellul, R., Galbally, I. E., Girgzdiene, R., Luppo, S., Mimouni, M., Nahas, A. C., Saliba, M., and Tørseth, K.: Gridded global surface ozone metrics for atmospheric chemistry model evaluation, Earth Syst. Sci. Data, 8, 41-59, doi:10.5194/essd-841-2016, 2016.

Stefan, S., Necula, C., and Georgescu, F.: Analysis of long-range transport of particulate matters in connection with air circulation over Central and Eastern part of Europe, Phys. Chem. Earth, 35, 523-529, doi:10.1016/j.pce.2009.12.008, 2010.

Stein, O., Schultz, M. G., Bouarar, I., Clark, H., Huijnen, V., Gaudel, A., George, M., and Clerbaux, C.: On the wintertime low bias of Northern Hemisphere carbon monoxide found in global model simulations, Atmos. Chem. Phys., 14, 9295-9316, doi:10.5194/acp-14-9295-2014, 2014.

Stevenson, D. S., Dentener, F. J., Schultz, M. G., Ellingsen, K., van Noije, T. P. C., Wild, O., Zeng, G., Amann, M., Atherton, C. S., Bell, N., Bergmann, D. J., Bey, I., Butler, T., Cofala, J., Collins, W. J., Derwent, R. G., Doherty, R. M., Drevet, J., Eskes, H. J., Fiore, A. M., Gauss, M., Hauglustaine, D. A., Horowitz, L. W., Isaksen, I. S. A., Krol, M. C., Lamarque, J.-F., Lawrence, M. G., Montanaro, V., Müller, J.-F., Pitari, G., Prather, M. J., Pyle, J. A., Rast, S., Rodriguez, J. M., Sanderson, M. G., Savage, N. H., Shindell, D. T., Strahan, S. E., Sudo, K., and Szopa, S.: Multimodel ensemble simulations of present-day and near-future tropospheric ozone, J. Geophys. Res., 111, D08301, doi:10.1029/2005JD006338, 2006.

Tanimoto, H.: Seasonal cycles of ozone and oxidized nitrogen species in northeast Asia 2. A model analysis of the roles of chemistry and transport, J. Geophys. Res., 107, 4706, doi:10.1029/2001JD001497, 2002.

Tanimoto, H., Sawa, Y., Matsueda, H., Uno, I., Ohara, T., Yamaji, K., Kurokawa, J., and Yonemura, S.: Significant latitudinal gradient in the surface ozone spring maximum over East Asia, Geophys. Res. Lett., 32, L21805, doi:10.1029/2005GL023514, 2005.

Travis, K. R., Jacob, D. J., Fisher, J. A., Kim, P. S., Marais, E. A., Zhu, L., Yu, K., Miller, C. C., Yantosca, R. M., Sulprizio, M. P., Thompson, A. M., Wennberg, P. O., Crounse, J. D., St. Clair, J. M., Cohen, R. C., Laugher, J. L., Dibb, J. E., Hall, S. R., Ullmann, K., Wolfe, G. M., Pollack, I. B., Peischl, J., Neuman, J. A., and Zhou, $\mathrm{X} .: \mathrm{NO}_{x}$ emissions, isoprene oxidation pathways, vertical mixing, and implications for surface ozone in the Southeast United States, Atmos. Chem. Phys. Discuss., doi:10.5194/acp2016-110, in review, 2016.

Valenzuela, J. and Pontt, J.: Real-Time Interharmonics Detection and Measurement Based on FFT Algorithm, in: Proc. Appl. Electron., 259-264, Institute of Electrical and Electronics Engineers (IEEE), Pilsen, 2009. van Donkelaar, A., Martin, R. V., Leaitch, W. R., Macdonald, A. M., Walker, T. W., Streets, D. G., Zhang, Q., Dunlea, E. J., Jimenez, J. L., Dibb, J. E., Huey, L. G., Weber, R., and Andreae, M. O.: Analysis of aircraft and satellite measurements from the Intercontinental Chemical Transport Experiment (INTEX-B) to quantify long-range transport of East Asian sulfur to Canada, Atmos. Chem. Phys., 8, 2999-3014, doi:10.5194/acp-8-2999-2008, 2008.

Vestreng, V., Ntziachristos, L., Semb, A., Reis, S., Isaksen, I. S. A., and Tarrasón, L.: Evolution of $\mathrm{NO}_{x}$ emissions in Europe with focus on road transport control measures, Atmos. Chem. Phys., 9, 1503-1520, doi:10.5194/acp-9-1503-2009, 2009.

Vinken, G. C. M., Boersma, K. F., Jacob, D. J., and Meijer, E. W.: Accounting for non-linear chemistry of ship plumes in the GEOS-Chem global chemistry transport model, Atmos. Chem. Phys., 11, 11707-11722, doi:10.5194/acp-11-11707-2011, 2011.

Wang, Y., Jacob, D. J., and Logan, J. A.: Global simulation of tropospheric $\mathrm{O}_{3}-\mathrm{NO}_{x}$-hydrocarbon chemistry: 1 . Model formulation, J. Geophys. Res., 103, 10713, doi:10.1029/98JD00158, 1998.

WHO: WHO Air quality guidelines for particulate matter, ozone, nitrogen dioxide and sulfur dioxide: Global update 2005, World Health Organization, Regional Office for Europe, 2005.

Wild, O. and Akimoto, H.: Intercontinental transport of ozone and its precursors in a three-dimensional global CTM, J. Geophys. Res.-Atmos., 106, 27729-27744, doi:10.1029/2000jd000123, 2001.

Xiao, Y., Logan, J. A., Jacob, D. J., Hudman, R. C., Yantosca, R., and Blake, D. R.: Global budget of ethane and regional constraints on U.S. sources, J. Geophys. Res., 113, D21306, doi:10.1029/2007JD009415, 2008.

Yevich, R. and Logan, J. A.: An assessment of biofuel use and burning of agricultural waste in the developing world, Global Biogeochem. Cy., 17, 1095, doi:10.1029/2002GB001952, 2003.

Yienger, J. J. and Levy, H.: Empirical model of global soilbiogenic $\mathrm{NO}_{x}$ emissions, J. Geophys. Res., 100, 11447, doi:10.1029/95JD00370, 1995.

Ziemke, J. R., Douglass, A. R., Oman, L. D., Strahan, S. E., and Duncan, B. N.: Tropospheric ozone variability in the tropics from ENSO to MJO and shorter timescales, Atmos. Chem. Phys., 15, 8037-8049, doi:10.5194/acp-15-8037-2015, 2015. 